\title{
Caring: from condition of human existence to professionalised integral care
}

\author{
Cuidar: da condição de existência humana ao cuidar integral profissionalizado \\ Cuidar: de la condición de existencia humana ao cuidado integral profesionalizado \\ Paulo Joaquim Pina Queirós*
}

\begin{abstract}
Background: Nurses assume caring as defining element of their work and knowledge.

Objectives: We sought to explain human caring, revealing its meanings throughout history and its current meaning for nursing.

Main topics under analysis: Reflection in the search for significances and meanings of caring for human beings, based on the classical texts The First Alcibiades by Plato, the drama Philoctetes by Sophocles, and the Fable/Myth Cura by Hyginus. Among other authors, Heidegger, Foucault and Boff recognise the essence of caring and assign it a useful meaning within the disciplinary framework of nursing.

Conclusion: We found an eminently human caring and first condition of humanity in plato; constitutive and founder of the human being in Hyginus; and inherent ethical imperative in Sophocles. These are key contributions to the current understanding of the concept of caring, its distinction from the concept of care provision, and clarification of the meaning of professional nursing care.
\end{abstract}

Keywords: nursing; philosophy; knowledge; nursing care.

\section{Resumo}

Enquadramento: Os enfermeiros assumem o cuidar como definidor do seu trabalho e do seu saber.

Objetivos: Procurámos ir ao encontro do cuidar humano, descobrindo suas significações ao longo do devir histórico e sentido atual para a enfermagem.

Principais tópicos em análise: Reflexão na procura de significações e sentidos que o cuidar tem para os humanos, partindo dos textos clássicos: Primeiro Alcibiades de Platão; o drama Filoctetes de Sófocles; e a fábula/mito Cuidar de Higino. Onde, entre outros, Heidegger, Foucault e Boff percebem a essência do cuidar e dão-lhe significado com utilidade para o enquadramento disciplinar da enfermagem.

Conclusão: Encontrámos um cuidar eminentemente humano e condição primeira de humanidade em Alcibíades, constitutivo e fundador de ser-humano em Higino; de inerente imperativo ético com Sófocles. Contributos indispensáveis para a compreensão atual do conceito cuidar, sua destrinça com o conceito prestação de cuidados e esclarecimento do sentido de cuidados profissionais de enfermagem.

Palavras-chave: enfermagem; filosofia; conhecimento; cuidados de enfermagem

* Post-doc ICBAS-UP, Ph.D., Coordinating Professor, Nursing School of Coimbra, 3020263, Coimbra, Portugal [pauloqueiros@esenfc.pt]. Address for correspondence: Rua do Açude, n. ${ }^{\circ}$ 150, Quinta da Mainça, Coimbra, 3000-435, Coimbra, Portugal.

\section{Resumen}

Contexto: Los enfermeros asumen el cuidado como un aspecto que define su trabajo y su saber.

Objetivos: Se pretende cumplir con el cuidado humano mediante el descubrimiento de sus significados a lo largo del desarrollo histórico y la dirección actual de la enfermería.

Temas principales de análisis: Para reflexionar sobre la búsqueda de significados y sentidos que el cuidado tiene para los humanos, se partió de los textos clásicos: El primer Alcibiades de Platón; el drama Filoctetes de Sófocles, y la fábula / mito Cuidar de Higinio. Entre otros, Heidegger, Foucault y Boff consideran la esencia del cuidado y le dan un significado con utilidad para situar la enfermería en un marco disciplinario.

Conclusión: Se encontró un cuidado eminentemente humano y una primera condición de humanidad en Alcibiades; constitutivo y fundador del ser humano en Higinio; imperativo ético inherente en Sófocles. Todos ellos aportaron contribuciones indispensables para llegar a lo que, actualmente, se entiende por cuidado, la distinción del concepto de atención y la aclaración en relación al sentido del cuidado profesional de enfermería.

Palabras clave: enfermería; filosofía; conocimiento; cuidados de enfermería.

\section{Received for publication: 11.10 .14 Accepted for publication: 07.04 .15}




\section{Introduction}

Caring has been characterised as central theme in nursing. Nurses find in this concept - caring/care - the definition of what they do, and of the knowledge that they use and create as a discipline.

Leininger (1978) distinguishes between care/caring, professional caring and professional nursing care. If we assume that care is the result of caring, the clarification of this concept becomes useful for epistemological reflection and discipline construction. If caring is an action and an attitude made available and used by human beings, what is the meaning assigned to it? How was this meaning structured? It is recent or founded in the early days of humanity? If it is a generalised human action and attitude, what is the meaning of its appropriation as key concept by a professional group and a discipline of knowledge (nurses/nursing)?

In order to clarify this set of questions, we analysed texts from Classical Antiquity, possibly the first texts where the concept of caring is explicitly mentioned. We found in the literature three classical texts of great interest for understanding the concept of caring, namely: The First Alcibiades by Plato (428/427348/347 B.C.); the drama Pbiloctetes by Sophocles (497/496-406/405 B.C.); and the Fable/Myth Cura by Hyginus (64-17 B.C.).

In the first text, Plato wrote the dialogues between Socrates (469/470-399 B.C.) and Alcibiades (450-404 B.C.) to reflect on the care of the self; in the second text, Sophocles, in a drama about the miserable life of Philoctetes, reveals the ethical dimension of caring; in the third text, Hyginus conveys the structuring essence of caring for the human dimension through a fable/myth.

The purpose of this theoretical reflection is to understand the profound meaning of caring and its contributions to discipline construction. The theoretical reflection starts with the identification of key texts for the concept of caring, their reading and personal reflective analysis, taking into account the interpretations of philosophers and other thinkers on these texts, and finding significances and meanings for the concept of caring in an interpretative confrontation with the current theoretical thinking in nursing.

\section{Development/Dissertation}

\section{The First Alcibiades by Plato}

According to Foucault (1994), it is in The First Alcibiades that the most remote philosophical elaboration of the care of the self may be found. There is still some dispute as to whether this text is by Plato and, given that its precise date is uncertain, some consider it to be apocryphal.

In The First Alcibiades, Plato writes a dialogue between the young aristocrat Alcibiades and Socrates. Its starting point is to know how he can gain the power to govern others (Dalbosco, 2006). "Socrates makes Alcebíades [Alcibiades] realise that his training to rule others would depend on his constant comparison with his rivals, but it would also, and above all, depend on how he would care of the self" (Dalbosco, 2006, p. 33). The care of the self in Alcibiades was determined by the following conditions: " 1 - those who should care of the self were youths destined to exercise power; 2 - the objective was the proper exercise of power; 3 the unique way in which to care of the self is to know thyself" (Damasio, 2014, p. 1).

According to Foucault (1994), knowing oneself is connected to the need to care of the self; it is the need to take care of the self that leads to knowing oneself. Caring for the self is thus a condition for knowing oneself, which is an idea implicit throughout the Greco-Roman culture and explicit after the Alcibiades. Take this example:

Socrates - And first of all, that we may not peradventure be deceived by appearances, fancying, perhaps, that we are taking care of ourselves when we are not, what is the meaning of a man taking care of himself? and when does he take care? Does he take care of himself when he takes care of what belongs to him? (Plato, 2007, p. 273)

And also,

Socrates - And can we ever know what art makes a man better, if we do not know what we are ourselves?

Alcibiades - Impossible.

...

Socrates - But whether easy or difficult, Alcibiades, still there is no other way; knowing what we are, we shall know how to take care of ourselves, and if we are ignorant we shall not know. (Plato, 2007, p. 275) 
Damasio (2014) mentions that by considering the existence of these two precepts, Foucault emphasises that "....in Alcebiades, however, the gnôthi seauton [know yourself] was always in a kind of subordination to the epimeleia heautou [care of the self], as a way of practical application of the general rule to care of himself" (p. 1).

In classical Greece [500-338 B.C.] and then in Hellenistic Greece [338-146 B.C.], the fundamental maxims of the art of living, which translate the major rule of conduct for both the personal and social life of the Greeks, prescribed not only the gnoti sauton, which means know yourself, but also the epimeleisthai sauton, that is, take care of yourself, care about yourself, worry about yourself. (Rocha, 2011, p. 9)

It is indeed Foucault (1994) who clarified the meaning of the care of the self for the Greeks as being one of the rules of conduct of social and personal life.

The notion of the care of the self has evolved over the centuries up to the present day and has accompanied the development of societies. It began by evolving from Classical Greece to Imperial Greece.

This emphasis on the care of the self, predominant in the Hellenistic era, was a result of the significant changes brought about by the cosmopolitan culture in the traditional way of living of the Greek citizen and population in general. The res publica moved from being governed by the city assemblies to being governed by the administrators of the Empire. Losing the status as a citizen, the Greek man became a subservient to the Emperor, and no longer found the protection that he once had in the Polis; he was coerced by the force of events to close in on himself, to activate new energies from within, new moral goals by which to live. Thus, the man discovered himself as an individual who, no longer relying on the tutelage of City-States, had to take the reins of his own destiny. (Rocha, 2011, p. 9-10)

In Greece, after the transition from City-States to Empire, the concept of care of the self is transformed and universalised. The care of the self was no longer only an obligation related to education, especially among the urban elites, and become that in which people should focus during their lives (Foucault, 1994).

When the essential is no longer naturally provided for by the city-state and when there is an individual focus on survival, the care of the self gains another dimension.

"The care for the self is only questioned or valued and realized as something essential for the human being from the moment that people become aware of their right to live and aware of the life style they lead." (Carraro \& Radunz, 2003 cited by Silva et al., 2009, p. 5). "The care of the self became a true cultural phenomenon as principle of all rational conduct ... We cannot ignore the fact that it has suffered a series of other changes during primitive Christianity, the medieval period, the Renaissance and the 17th century." (Damasio, 2014, p. 1)

Castro, Viana, and Bara (2010) mention Foucault by saying that "the most important reason for which the precept of care of the self was erased from the history of western thought is the cartesian moment ... the birth of modern rationality in the 17th century" (p. 1282). This rationality qualifies the precept know yourself and disqualifies the care of the self.

The care of the self is requalified later on in The Human Comedy by Balzac (1830-1840), "this work includes the whole being of the subject to turn his life into a self-completed art as in the culture of the self during the Hellenistic period ..." (Castro et al., 2010, p. 1297)

From the point of view of the nursing discipline, the concept of care of the self becomes apparently close to the concept of self-care. In this regard, Silva et al. (2009) mentions that

Self-care is focused on the paradigm of totality, in other words, the human being is seen as a summative entity ... Care of the self, on the contrary, is bonded to the paradigm of simultaneity... the person is not a sum, for the whole is bigger than the sum of all parts .... (p. 7) Thus, according to these authors, self-care is related to the paradigm of totality, in which health has acquired an objective, encompassing nature, as a result of the sum of all parts. On the other hand, the care of the self is related to the paradigm of simultaneity which values what is subjective in the human being. They are both important concepts to the current perception of caring in nursing care.

\section{Philoctetes by Sophocles}

Summary of the drama by Carvalho (2008):

Philoctetes participated in the expedition of the Atreidae against Ilium in command of seven 
ships. He never reached the Trojan shore: in Chryse, at the altar of the deity who gave name to the island, he was bitten by a snake in the foot. The wound was voraciously infected and pestilent, making him useless for the mission; disgusting pus oozed from it, intolerable pain made him scream and moan in such a horrible, wild and gloomy way that libations and sacrifices were disturbed. Ulysses persuaded the other commanders to abandon him in the remote island of Lemnos; nine years later, Helenus, the Trojan soothsayer, captured by the Cephalenius, foretold that Troy would not fall without Philoctetes and his bow ....

The tragedy of Sophocles begins with Ulysses arriving at Lemnos, together with Neoptolemus, with the mission to bring the weapon and the hero. As he could not expose himself, fearing revenge ... [from Philoctetes], and aware that force and persuasion would be useless, he perversely uses the young Neoptolemus, instructing him to deceive Philoctetes, earning his trust to follow him, believing that he would take him home.

The son of Achilles [Neoptolemus] begins by refusing it, in the name of moral principles, but he obeys. Ulysses' stratagem works. Philoctetes has a major attack of violent pain and, before falling asleep, he gives the young man the bow. When he wakes up, he realises that he was once again betrayed and abandoned, helpless, at the mercy of wild beasts, without being able to provide for subsistence. Neoptolemus, already moved by his admiration for the existential force of the hero and piety for his torments, revolves himself around the moral crisis that instigates him to follow the sound principles of his true nature; with a pang of conscience, he reveals the truth, comes back and returns the bow, contradicting Ulysses. Philoctetes resists to his threats and the benevolent arguments of the young man, that ensure him cure and glory in Troia, refusing to help those responsible for his misery, and persuading Neoptolemus to return home, abandoning the Atreidae army to a disastrous end.

As the universal order cannot be distorted and to fulfil the dark plan that governs it, Heracles appears as the deus ex machina, persuading them to navigate to Troia and conquer it, ensuring the hero's reconciliation with himself, history and the divine. (Carvalho, 2008, p. 156)

We are dealing with abandonment, abandonment of a human being in suffering, and with taking advantage of disadvantage, but also with a pang of consciousness that leads to compassion and caring.

According to Gemelli (2010), there are in Philoctetes intricate and strained relationships between the characters who need each other not only to achieve or reach their goals, but even to define them ... Neoptolemus is the most susceptible of the three characters in this tragedy for his still potential condition ... The young man in this mission finds or witnesses, for the first time, all the grandeur and baseness resulting from the decisions of men. (Gemelli, 2010, p. 32)

Based on the paradigmatic character of Philoctetes, Carvalho (2008) proposes himself to evaluate the amount of pain present throughout our lives, [and that] have made philosophy, literature and art speculate" ... "no one suffered like him, according to the chorus of Sophocles ("but I know of no other, by seeing or hearing, that is, no mortal, tied to a loathlier fate than his"), I will use his endless pain - the physical torment, the insult of being banished, the loneliness of being disabled, the devouring hatred, the metaphysical despair .... (Carvalho, 2008, p. 155)

The tragedy Philoctetes, by Sophocles, takes us to the ethical dimension of caring, calling for "compassion toward the Man at the singular scale" (Zagalo-Cardoso \& Silva, 2010, p. 84).

These authors ask themselves:

What ethical message can be found in this beautiful narrative, already with two thousand and five hundred years, to help us reflect on the protection of individuals with physical "disability"? Looking at the example of Neoptolemus, should we sympathise with Philoctetes only because of his wounds or for seeing in him a different side, another human side that demands from us a respectful attitude towards all human beings. (Zagalo-Cardoso \& Silva, 2010, p. 86)

Zagalo-Cardoso and Silva (2010) continue asking themselves

since we all need and provide care, we are not exactly a burden to others as the Greek hero was treated by his companions. If we think about the lack of Care from a broader perspective, we 
will find that abominable activity within our own homes, as it is also natural that the elderly and the sick see themselves with less physical and psychological skills to perform their activities: it is for no other reason than for our lack of care that they are often forgotten .... (Zagalo-Cardoso \& Silva, 2010, p. 86)

The ethical dimension is intimately related to caring, as when we are impelled to care, we are necessarily responding to an option, and finding an assertive or non-assertive solution, a dilemmatic response to a problem at hand.

\section{The Fable/Myth Cura by Hyginus}

Borges-Duarte (2010), in the text A Fecundidade Ontológica da Noçao de Cuidado. De Heidegger a Maria de Lourdes Pintasilgo, reminds us that in section 42 of Being and Time, Heidegger cites the fable/myth Care, gathered by Hyginus in his collection Fabulae, number 220, reproducing it as follows:

Once when Care was crossing a river, she saw some clay; she thoughtfully took up a piece and began to shape it. While she was meditating on what she had made, Jupiter came by. Care asked him to give it spirit, and this he gladly granted. But when she wanted her name to be bestowed upon it, Jupiter forbade this, and demanded that it be given his name instead. While Care and Jupiter were arguing, Earth (Tellus) arose, and desired that her name be conferred upon the creature, since she had offered it part of her body. They asked Saturn to be the judge. And Saturn gave them the following decision, which seemed to be just: "Since you, Jupiter, have given its spirit, you should receive that spirit at death; and since you, Earth, have given its body, you shall receive its body. But since Care first shaped this creature, she shall possess it as long as it lives. And because there is a dispute among you as to its name, let it be called homo, for it is made out of humus (earth). (Borges-Duarte, 2010, p. 118-119).

Rocha (2011) draws attention to the fact that "the Latin term Cura, used by Hyginus, has many meanings, among which the treatment of diseases ... In this fable, the term Cura can be translated as care, or as anguish, concern, anxiety and solicitude". (p. 4). (Rocha, 2011) also mentions that,

when it came to naming the shaped figure, a consensus was not reached among the characters.
As Jupiter, the god of the sky and the goddess of the earth, Tellus, did not reach a consensus on the name of the figure, they asked Saturn, the god of time, to settle the matter. It is precisely in the verdict pronounced by Saturn [god of time] that one can find the essence of Hyginus' narrative. (Rocha, 2011, p. 10)

According to Borges-Duarte (2010),

for me, the essential aspect seems to be that the human creation is not coined neither by spirit, nor by body, which are borrowed in life, but dissolved and returned to whom borrowed them at death, but by that which gave it shape - Care - that penetrates it and keeps it alive ... (BorgesDuarte, 2010, p. 120)

Adding

it is not the distinction between soul and body and its constitutive union that ontologically characterises the human being, but taking its being in is being, caring for it, for the self, caring for and taking care, unveiling itself by and in living. It is this eminently temporal mark that formally defines the Dasein as "being-there", Heidegger's designation of the human being in its supreme dignity. (Borges-Duarte , 2010, p. 120)

In Silva et al. (2009) we find some clarification "he cure executes the constitutive part, but time is the one to make all decisions, for man is nothing if time and the world are disregarded. The man- being only exists while being-in-time." (p. 3). As a lived being, a living being or one with the potential to live, it is not spirit or matter, it is a life project and/or accomplishment.

Laviola (2013) mentions that Heidegger In Being and Time "based on anxiety as opening of possibilities and finding oneself from within ... presents the being of Dasein as care." (p. 22). The human being is thus understood "as being-in-the-world. And that shall make him anxious" (p. 21).

The Dasein encompasses three intimately related ontological fundamentals: existentiality - the being of being-there - related to freedom of choice; facticity -being-in, being-self-ahead, - anywhere, a being-inthe-world; being-fallen, fleeing its ownmost self, in anxiety. And, it is precisely because it is a power-to-be, that its way of being is not an objectively established or essentially determined reality.

Heidegger (2012) states that "According to Scheler, the person can never be thought of as a thing 
or a substance. Rather it is "the immediately coexperienced unity of experiencing - not just a thing merely thought behind and outside of what is immediately experienced" (p. 155).

About the crucial importance of care in Heidegger, Boff (1999) argues that

care is an existential a priori which as such lies before every factical attitude and situation of the human being, which means that it always lies in them. That is, to care is at the very root of the human being, it is there before anyone does anything. And if someone does do anything, it is always accompanied by, and permeated with, care. (Boff, 1999, p. 13)

The "concept of care as being-with-others" where "its understanding begins with the use of tools and is followed by the solicitude for others". (Almeida, 2008, p. 14).

According to Roselló (2009) "caring,... has the same origin as the human being, because it is Care that creates and protects the individual. For this reason, the action of caring reveals something very specific of the individual's humanity - its intimate constitution." (p. 118).

And also,

through the action of caring, the human being is humanised, that is, fully assumes his humanity and, also, highly resembles his creator, which means that the action of caring ennobles the human being, elevates him to the category of the gods, since, through it, the human being imitates his creator, the god Care. (Roselló, 2009, p. 118)

Boff (1999) also believes that "care is the fundamental ethos of the human being" (p. 1), a minimum ethics that preserves life, social relations and nature, and is present in the essence of the human being as care. According to Boff (1999) "care only exists when one who is of prime importance to me exists and, so, I dedicate myself to that person" (p. 2), adding Silva, et al. (2009) "taking care of someone is to esteem and estimate for one whose complete well-being is our absolute goal." (p. 2).

Roselló (2009) cites Pellegrino (1985) saying that integral care is a moral obligation of health professionals, encompassing four senses: compassion; helping in autonomy; inviting to wanting to help; putting someone at the centre of action. According to Silva et al. (2009) care is "devotion, solicitude, diligence, zeal, attention, and tepid treatment; it should be a way in which one forgets about oneself and focuses on the other ..." (p. 2).

Returning to a Heideggerian perspective and within a psychoanalyst framework, Rocha (2011) providing conceptual richness to caring, mentions that "clinical practice is dedicated to caring for clients with concern, devotion and solicitude. Thus, Heidegger's distinction in relation to Sorge (care) between Besorgen (concern) and Fürsorgen (solicitude) opens new possibilities ..." (p. 23).

Returning to Boff (1999)"Caring is more than an act, it is an attitude. Therefore, it covers more than a moment of attention, zeal and unveiling. It represents an attitude of occupation, concern, responsibility and affective involvement with the other" (p. 12).

In Laviola (2013) "the solicitude of caring for the other, that is, the concern-with is a constitutive element of the individual. It is part of his mode-of-being. When he relates to others, the mark of concern, of care, stands out" (p. 26). According to this author, Heidegger uses this myth "exactly to illustrate that solicitude is the mark of the human being in the world. It would be an integral care, which covers all dimensions of the human being..." (p. 10).

Caring is much more than providing care (doing), goes beyond the directed action; it is readiness, solicitude, and compassion. As Hesbeen (2001) so well expressed, many health professionals

may, either regularly or occasionally, practice their profession without, for various reasons, caring for or being really attentive to the uniqueness of the patient. In these cases, they are providing care but not caring. The help that they provide - and that should not be underestimated - is, in principle, limited as it essentially depends on acts or tasks aimed at the individual's body - body-object -, but not truly at the person - body-subject. (Hesbeen, 2001, p. 17)

Another dimension is the extension of caring, going beyond the act itself (care provision) to the attitude (concern, solicitude, readiness, compassion - caring). This reflection may help opening up the concept to the meaning of caring in nursing, with a view to disciplinary specificity. Queirós (2014) in a study on the disciplinary concepts used by undergraduate and master nursing students, concluded that "caring is the most widely used and appropriated term and concept." (p. 40). 
However, it is not always possible to understand if nurses have interiorised the conceptual richness and operational meaning of the term caring.

\section{Conclusion}

According to the abovementioned Leininger's classification of care (1978), professional nursing care, as it is more than providing care, is also more than the merely professional care of persons or things (caring for the hair, nails, shoes, clothes etc.). To that extent, while drawing closer to the notion of non-universal professional caring (for example, our mothers' care), it professionalises it and associates it with a more specific understanding and context of the nursing discipline - the professionalisation of the caring attitude (with concern, compassion, solicitude, among others). The caring attitude is based on and founded upon the inherently human caring, which is the first expressed and perceived condition of humanity since Alcibiades; constitutive and founder of the human being as reports Hyginus; with an inherent ethical imperative, as it is evident in Philoctetes.

The caring attitude in professional nursing care is different from other professional care (non-nursing) and informal care, as, in addition to considering the action itself (care provision), it also considers solicitude, compassion, and readiness in a directed, intentional, organised, and integrated way.

Therefore, caring in nursing is perceived as professionalised integral care.

The care of the self and others, self-care or care with those around us are connected and inherent to our condition of human beings. It is constantly questioned, especially in the form of ethical dilemma, and provided with several nuances. It has accompanied the development of civilisation since classical antiquity, and is perceived today as a professionalised action and attitude, embodying nursing.

In nursing, caring, as condition of human existence, is understood as professionalised integral care which is maximised and made available. When in the form of an action, it uses and generates its own knowledge which, in a symbiosis with other fields of knowledge, being recreated and systematised, gives rise to the specific knowledge of nursing.

\section{References}

Almeida, R. S. (2008). O cuidado na primeira seção de ser e tempo. "Existência e Arte"- Revista Eletrônica do Grupo PET- Ciências Humanas, Estética e Artes da Universidade Federal de S. João Del-Rei, 4(4), 1-16.

Boff, L. (1999). Saber cuidar: Ética do Humano: Compaixão pela Terra. Petrópolis, Brasil: Vozes. Retrieved from http// pt.slideshare.net/sofphyazul/saber-cuidar-completo

Borges-Duarte, I. (2010). A fecundidade ontológica da noção de cuidado. Ex aequo, 21, 115-131.

Carvalho, J.V. (2008). As dores de Filoctetes. Comunicação \& Cultura, 5, 155-170.

Castro, F.C., Viana, T.C. \& Bara, O. (2010). O "cuidado de si" em Platão e em Balzac: Algumas páginas da história da subjetividade. Revista Mal-Estar e Subjetividade, 10 (4), 1271-1300.

Dalbosco, C. A. (2006). Corpo e alma na velhice: Significação éticopedagógica do "cuidado de si mesmo". Revista Brasileira de Ciências do Envelhecimento Humano, 3 (1), 22-37.

Damasio, C.R. (2014). Michel Foucault e o cuidado de si. Retrieved from http://www.espacoacademico.com. br/073/73damasio.htm

Foucault, M.(1994). Dits et écrits. Vol. IV, pp. 783-813. Paris: Gallimard.

Gemelli, C. L. (2010). A disputa por Neoptólemo no Filoctetes de Sófocles (Trabalho final de curso). Universidade Federal do Rio Grande do Sul, Instituto de Letras, Departamento de Letras Clássicas e Vernáculas, Brasil.

Heidegger, M. (2012). Ser e Tempo. Petrópolis, Brasil: Vozes.

Hesbeen, W. (2001). Qualidade em enfermagem: Pensamento e ação na perspetiva do cuidar. Loures, Portugal: Lusociência.

Laviola, B.R. (2013). O ser que cuida e é cuidado na perspetiva do dasein de Heidegger. Belo Horizonte, Brasil: Instituto S. Tomás de Aquino.

Leininger, M. (1978). The phenomenon of caring: Importance, research questions and theoretical considerations. In Leininger, M. (1981), Caring, an essential buman need: proceedings of three National Caring Conferences. Part I; The phenomena and nature of caring. (pp. 3-16). Salt Lake City, USA: University of Utah.

Pellegrino, E. (1985). The caring ethics: the relation of physician to patient. In A. H. Bishop \& J. R. Scudder (Eds.), Caring, curing, coping: Nurse, physician, patient relationships. pp 8-30. Birmingham, England: University of Alabama Press.

Platão. (2007). Platão diálogos: Fedro: Cartas: O primeiro Alcibiades $2^{\mathrm{a}}$ ed. (revisada, tradução direta do grego Carlos Alberto Nunes). Belém-Pará, Brasil: Editora universitária Federal do Pará/EDUFPA 
Queirós, P. (2014). Conceitos disciplinares em uso por estudantes de licenciatura e de mestrado em Enfermagem. Revista de Enfermagem Referência, 4(2), 29-40.

Rocha, Z. (2011). A ontologia Heideggeriana do cuidado e suas ressonâncias clínicas. Síntese: Revista de Filosofia, 38(120), $71-90$

Roselló, F.T (2009). Antropologia do cuidar. Petrópolis, Brasil: Vozes.
Silva, I. J., Oliveira, M.F., Silva, S.E., Polaro, S. H., Radunz, V., Santos, E. K. \& Santana, M.E. (2009). Cuidado, autocuidado e cuidado de si: Uma compreensão paradigmática para o cuidado de enfermagem. Revista Escola Enfermagem USP, 43(3), 697-703.

Zagalo-Cardoso, J.A. \& Silva, A. S. (2010). A ética do cuidado à luz da fábula/mito de Higino e da tragédia Filoctetes, de Sófocles. Revista Portuguesa de Filosofia, 66(Fasc.1), 81-88. 